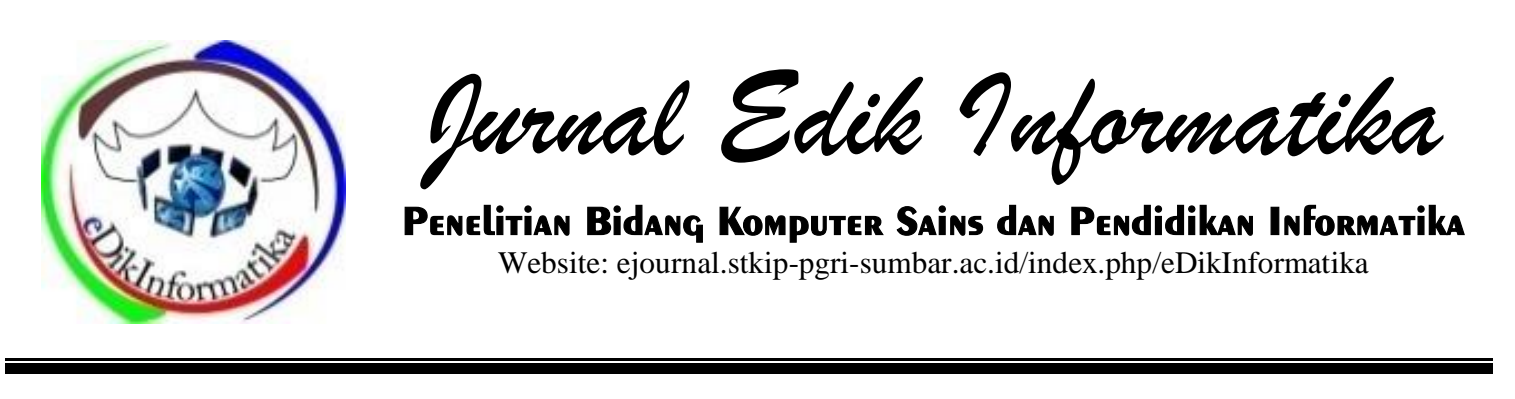

\title{
FORENSIC IMAGE FORGERY MENGGUNAKAN TEKNIK WAVELET DENOISING PADA CITRA 2D
}

\author{
Azmi Rahmat Endardhi ${ }^{1}$, Aniq Noviciatie Ulfah $^{2}$, Nora Lizarti ${ }^{3}$, Susandri ${ }^{4}$, Koko \\ Harianto \\ ${ }^{1,2}$ Sekolah Tinggi Manajemen Informatika dan Komputer Amik Riau \\ azmirahmat98@gmail.com
}

\begin{tabular}{|c|c|}
\hline INFO ARTIKEL & Abstract \\
\hline $\begin{array}{l}\text { Diterima: } \\
\text { 05 Mei 2021 } \\
\text { Direview: } \\
\text { 07 Mei 2021 } \\
\text { Disetujui: } \\
\text { 28 Mei 2021 }\end{array}$ & $\begin{array}{l}\text { Technological advances have taken advantage of digitalization } \\
\text { which has been widely available and is very easy to find and use, } \\
\text { so many people misuse images for things that harm others. This } \\
\text { research builds a system to detect image forgery for copymove } \\
\text { using Discrete Wavelet Transform (DWT) with two dimensions } \\
\text { to detect image forgery. This system is built with steps; input }\end{array}$ \\
\hline Kata Kunci: & $\begin{array}{l}\text { Image formats } J P G, P N G, B M P, R G B \text { image conversion to } \\
\text { grayscale image, Threshold process, Discrete Wavelet }\end{array}$ \\
\hline $\begin{array}{l}\text { Forensic Image } \\
\text { forgery, Wavelet } \\
\text { denoising, Citra 2D }\end{array}$ & $\begin{array}{l}\text { Transform (DWT) decomposition, } 8 x 8 \text { matrix calculation, Shift } \\
\text { Vector process, and the process of displaying image block } \\
\text { results. Based on the results of this study, the Discrete Wavelet } \\
\text { Transform is able to read the copy move through the noise that } \\
\text { exists in the image without disturbing the original image, the } \\
\text { copymove image will be detected by the system by reading each } \\
\text { image area by looking at the difference in each pixel that } \\
\text { produces the noise value. The noise value is processed by } \\
\text { comparing the noise value of the previous pixel so that it } \\
\text { produces a difference, therefore, the system can determine the } \\
\text { image area using the copymove technique and block the pixel }\end{array}$ \\
\hline
\end{tabular}

\section{PENDAHULUAN}

Perkembangan teknologi di Indonesia diibaratkan seperti dua sisi mata uang yang dapat memberikan dampak positif dan dampak negatif bagi penggunanya. Salah satu dampak positif tersebut adalah mempermudah orang dalam memesan makanan, membeli alat elektronik, dan memesan ojek online. Meskipun demikian perkembangan teknologi juga memiliki dampak negatif seperti Adiktif, meningkatnya penipuan, meningkatnya pemalsuan gambar. Meningkatnya kejahatan dikarenakan banyaknya tools/alat yang dapat mempermudah seseorang dalam memanipulasi produk digital.

Kasus rekayasa terhadap foto sangat sering terjadi di Indonesia bahkan tak jarang menimpa publik figur seperti pejabat negara dan artis kenamaan tanah air. Salah satu contoh kasus mantan 
pimpinan Komisi Pemberantasan Korupsi atau KPK Abraham Samad. Kasus foto mesra yang diduga merupakan pejabat Negara itu dengan seorang Putri Indonesia 2014 menggemparkan masyarakat Indonesia pada tahun 2015 lalu (Yan Mitha Djaksana, 2018). Banyak pihak yang salah menggunakan teknologi yang sekarang ini lagi berkembang pesat. Banyak kasus tentang citra sering menjadi topik hangat di media baik online maupun offline. Tak jarang kasus citra tersebut diangkat ke pengadilan, namun kasus citra tersebut yang sering di tolak karena kebanyakan dari citra palsu tidak ter-integrity.

Banyak kasus yang dari tahun ke tahun mengenai citra palsu dengan berbagai topik yang memanipulasi citra yang sangat mudah didapat atau ditemukan di media. Dampaknya membuat citra tersebut rentan untuk disalahgunakan oleh pihak yang tidak bertanggung jawab untuk berbagai kepentingan. Citra merupakan sebuah gambar dua dimensi. Citra tergolong menjadi dua golongan yaitu citra diskrit dan citra continue. Citra continue merupakan sebuah citra yang dihasilkan dari optik atau mata manusia dengan memdapatkan sinyal seperti, kamera analog sehingga citra nya terlihat nyata sedangkan citra diskrit merupakan citra yang mendapatkan hasil dari citra countinue dengan proses digitalisasi dengan beberapa system optik yang sudah digitalisasi kemudian menghasilkan sebuah citra diskrit misalnya, kamera diskrit dan scanner. Citra diskrit merupakan sebuah citra digital yang memiliki nilai 1 dan 0.(Purwandari, Vatresia, \& Siburian, 2019). Seperti pada kasus ditahun 2018 yang dikemukakan oleh (Aminudin, 2018) bahwa telah terjadi kasus manipulasi foto yang menimpa seorang dosen di salah satu universitas. Foto tersebut dimanipulasi oleh seseorang yang tidak bertanggung jawab. Tahun 2019 terjadi lagi kasus manipulasi foto yang disampaikan (Lesmana, 2019) yang memberitakan bahwa terjadi kasus manipulasi foto yang dilakukan oleh seseorang melalui sosial media.

Paparan di atas merupakan bentuk Image Forgery atau manipulasi citra yang sering digunakan oleh sebagian orang dalam memanipulasi sebuah produk digital dan mengakibatkan makna yang terkandung di dalam sebuah citra menjadi berbeda. Citra yang sudah menggunakan image forgery membuat sebagian individu yang membacanya menjadi kesulitan dalam membedakan citra yang asli dan citra yang palsu, tentunya hal ini sangat berbahaya, karena citra palsu sering memberikan kerugian bagi pihak yang disebutkan di dalam citra tersebut. Menurut (Lizarti, Sugiantoro, \& Prayudi, 2017) Forensic pada citra digital adalah ilmu yang digunakan untuk pelestarian, pengumpulan, validasi, identifikasi, analisa, interpretasi, dokumentasi, dan presentasi barang bukti digital yang diperoleh dari sumber digital. Prinsipprinsip dasar forensic menurut (Lizarti et al., 2017) antara lain: 1) Sebuah Lembaga hukum sangat dilarang dalam mengubah data atau barang bukti yang tersimpan berupa file-file yang berada di dalam elektronik yang akan dibawa ke Lembaga pengadilan. 2) Selama proses pemeriksaan terdapat beberapa catatan penting yang dilakukan di dalam pemeriksaan setiap file-file yang berada di dalam elektronik saat investigasi sedang berlangsung. 3) Person in Charge dalam pemeriksaan memiliki tanggung jawab dalam pemeriksaan barang bukti secara keseluruhan selama proses investigasi berlangsung.

Suatu Teknik dibutuhkan untuk memecahkan permasalahan $\mathrm{di}$ atas. Teknik wavelet denoising pada citra 2D dapat membantu proses deteksi rekayasa citra. Dimana Teknik ini dapat 
membedakan struktur dari sebuah citra. Menurut (Amin et al., 2015) citra 2D merupakan citra yang dapat memperlihatkan permukaan dari suatu bidang di sisi objek dari sebuah citra. Citra 2D dapat mengamati suatu objek yang memiliki kecatatan dari sebuah informasi yang ada di dalam citra tersebut tetapi, citra 2D memiliki kekurangan dimana tidak bisa dalam menentukan sebuah lokasi dan bentuk geometri dari cacat tersebut. Wavelet denoising berguna untuk mendeteksi nilai/noise yang dihasilkan oleh citra tersebut melalui pixel yang dihasilkan citra copymove dengan citra asli dapat diketahui melalui perbedaan yang di hasilkan oleh nilai pixel yang ada di wilayah citra dan dengan tetap menjaga karakteristik citra tersebut, sehingga informasi yang ada di dalamnya tidak terganggu dan mendapatkan citra yang lebih akurat. Discrete Wavelet Transform merupakan metode yang digunakan dalam menjalankan teknik dari wavelet ini. Menurut (Vega, Orozco, Villalba, \& Hernandez-Castro, 2018) Discrete Wavelet Transform (DWT) memberikan representasi unik diskriminatif yang dapat mengukur struktur yang vital dan menarik dari bagian yang tepi dengan secara detail dan memberikan resolusi yang baik untuk beberapa koefisien dan sangat efektif secara komputasi untuk data yang dengan jumlah sedikit untuk di gunakan dengan fungsi wavelet seperti gelombang kecil yang dapat memusatkan dari waktu ke waktu agar dapat menganalisis setiap frekuensi stasioner yang di dapat, fenomena non-stasioner dan waktu. Dalam transformasi, wavelet merupakan representasi sinyal yang paling kuat dari pemprosesan gambar dan sinyal . Teknik ini dapat membedakan mana citra/gambar yang benar dan mana gambar yang sudah diedit sehingga dapat terhindar dari bahaya image forgery.
Penelitian yang dilakukan Lizarti dan kawan-kawan pada tahun 2017 mengenai penerapan composite logic dalam mengkolaborasikan framework dengan topik multimedia forensik. Hasil penelitian ini menunjukkan Bahwa metode Composite Logic dapat digunakan sebagai tahapan-tahapan untuk membangun sebuah Fremework Multimedia Forensic yang teridentifikasi dengan cara mengidentifikasi, mengkolaborasi dan mengklasifikasi dengan beberapa framework Multimedia Forensik yang berbeda menggunakan pemodelan logic yang berdasarkan terminologi dan composite role model dengan menghasilkan 5 tahapan utama dan 30 sub tahapan. Sementara itu, Endina Putri Purwandari, Arie Vatresia, Sudarti Siburian pada 2019, telah melakukan penelitian mengenai discrete cosine transform (DCT) dan scale invariant feature transform (SIFT) dengan topik deteksi image splicing pada citra. Hasil penelitian menyampaikan bahwa aplikasi yang dihasil kan dapat mendeteksi pemalsuan image splicing dengan mengkolaborasikan metode Discrete Cosine Transform dan Scale Invariant Feature Transform (SIFT). Penelitian yang dilakukan oleh Derwin Rony Sina, Agus Harjoko pada tahun 2016 telah melakukan penelitian mengenai exact match, DWT haar dan Daubechies dengan topik deteksi copy move forgery pada citra. Hasil penelitian ini menunjukkan bahwa aplikasi yang dihasilkan dapat mendeteksi Copymove Image Forgery dengan menggunakan metode yang di usulkan dengan baik, dengan kombinasi metode Exach Match yang $8 \times x \quad 8$ menghasilkan keakuratan daerah deteksi, waktu eksekusi yang tidak terlalu lama dan area dari False Match yang kecil untuk blok $4 \mathrm{x} 4$. Penelitian di atas telah mengkaji Forensic Image Forgery. Dalam penelitian in juga mengkaji Forensic Image Forgery, 
namun keterbaruan penelitian ini yaitu menggunakan Teknik Wavelet Denoising pada Citra 2D. Penelitian ini bertujuan untuk mendeteksi image forgery copymove dengan menggunakan algoritma DWT untuk menentukan wilayah dari citra yang dimanipulasi. Hal ini bertujuan untuk memberikan kemudahan dalam menentukan citra yang asli dan citra palsu sehingga masyarakat tidak tertipu dengan berita yang tidak benar.

\section{METODE}

Penelitian ini diawali dengan pelaksanakan analisis kebutuhan system yang dilaksanakan sebagai berikut:

1. Membaca citra masukkan dengan format JPG, PNG, BMP

2. Melakukan proses konversi citra masukan (mengganti citra masukkan dari citra RGB menjadi citra grayscale)

3. Melakukan proses threshold setiap pixel pada citra untuk memberikan warna kontrak setiap nilai pixel yang melewati ambang batas, dapat membedakan objek dengan background

4. Melakukan proses dekomposisi DWT, membagi citra menjadi 4 subband LL, HL, LH, HH untuk menentukan nilai yang terdapat dari masing wilayah masing-masing subband tersebut

5. Menghitung nilai dari setiap proses dekomposisi DWT untuk setiap pixel yang dihasilkan

6. Melakukan proses shift vector untuk nilai baris dan kolom yang dihasilkan dengan pixel dengan jumlah nilai yang dihasilkan

7. Melakukan proses bloking untuk nilai yang dikelompokkan oleh proses sebelumnya terhadap wilayah citra copymove.

\section{Rancangan Pemrosesan Data}

Penelitian menggunakan langkah kerja metode dalam deteksi citra copymove pada gambar 1. Penjelasan sub-bab berikut merupakan penjelasan mengenai langkah kerja metode secara detail.

\section{Input citra format JPG, PNG, BMP}

Proses ini merupakan awal untuk mulai mendeteksi citra copymove dengan menerima data berupa citra dengan memiliki tiga format yang di tentukan dalam sistem yaitu JPG, PNG, dan BMP (Derwin Rony Sina, 2016), sehingga selain format yang sudah di tentukan maka sistem tidak dapat memproses citra terssebut.

\section{Konversi Citra RGB Menjadi Citra Grayscale}

Pada proses ini sistem akan merubah setiap pixel menjadi warna grayscale apabila, gambar terebut berukuran 200x200 maka jumlah pixel yang di proses untuk menjadi grayscale 4000 pixel di dalam satu gambar. Pixel pertama sampai pixel ke 4000, sistem harus menentukan nilai yang dihasilkan perpixel jadi, nilai red, grean dan blue berapa hasilnya setelah itu, dibagi 3 sampai pixel 4000 untuk proses grayscale tersebut.

\section{Proses Threshold}

Pada proses threshold ini, sistem membatasi setiap nilai pixel yang dihasilkan oleh citra grayscale tersebut, dalam proses ini sitem membatasi untuk nilai thresholdnya yaitu 90 sehingga untuk nilai yang dihasilkan setiap pixel memiliki nilai di bawah nilai threshold maka sistem akan mengganti warna pixel menjadi merah tetapi, apabila nilai pixel yang dihasilkan memiliki nilai di atas 90 maka untuk warna pixel tersebut menjadi warna putih, maka untuk pixel selanjutnya dihitung setiap pixel sampai pixel 4000. 


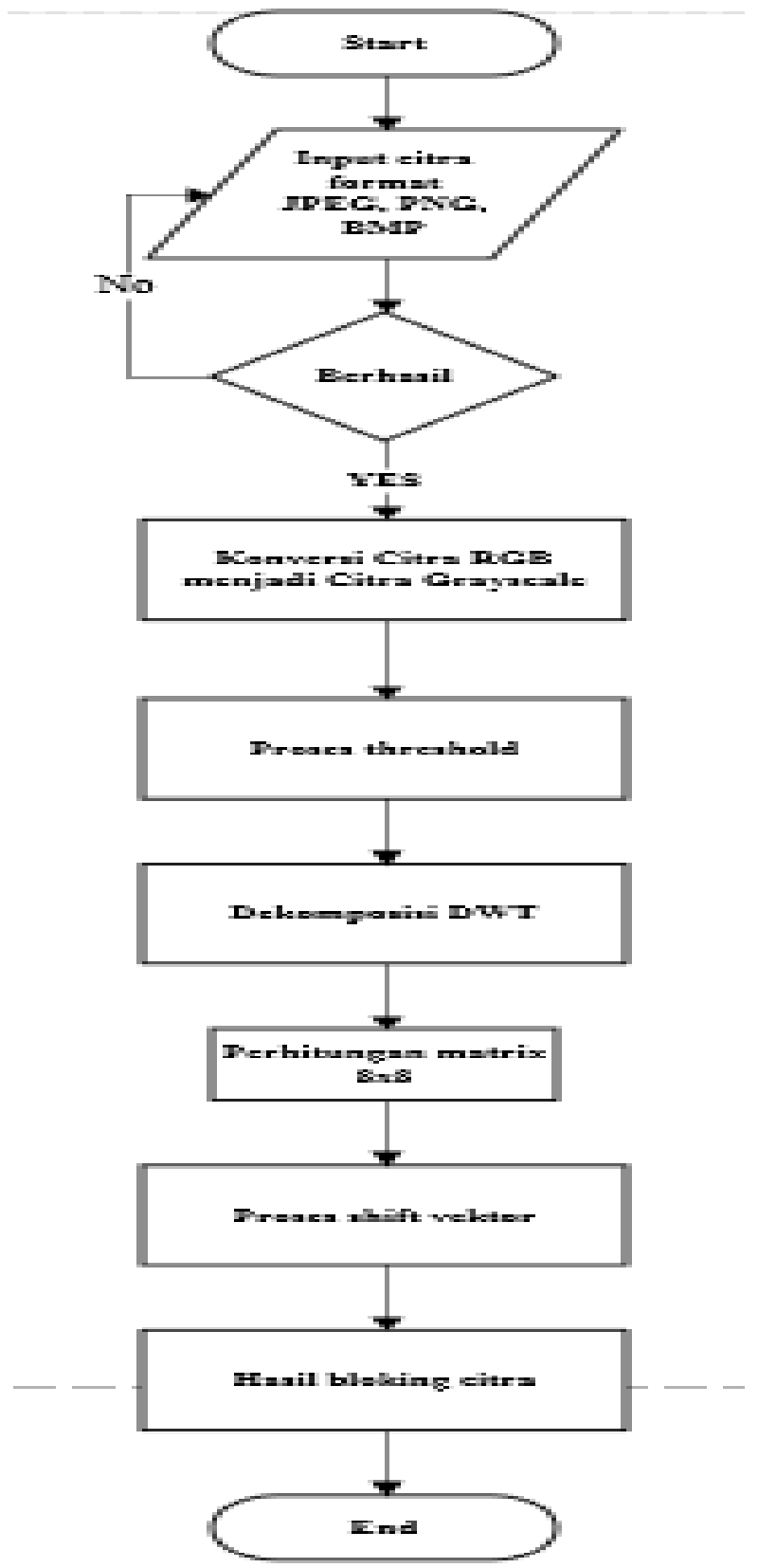

Gambar 1. rancangan alur pemrosesan data

\section{Dekomposisi DWT}

Pada proses ini sistem melakukan proses awal dalam menjalankan algoritma DWT, proses ini citra hasil threshold tersebut akan mulai melakukan proses dekomposisi DWT. Citra tersebut akan dipisahkan menjadi 4 subband dan subband tersebut dipisah menjadi 4 lagi sampai mendapat nilai setiap zona
tersebut(Yadav \& Rathore, 2012). dengan tujuan untuk lebih spesifikasi dalam menentukan citra copymove tersebut dan untuk menghitung nilai LL, HL, LH, HH setiap subband terhadap citra tersebut. Dapat dilihat pada gambar 2

\section{Perhitungan matrik 8x8}


Pada proses ini citra hasil dari nilai dekomposisi atau pemisahan tersebut, akan melalui proses untuk menghitung nilai dari setiap pemisahan yang dilakukan sistem sampai mendapat nilai yang dibutuhkan untuk setiap pixel yang dihasilkan oleh setiap subband menggunakan matrik $8 \times 8$ hasil dekomposisi tersebut untuk menentukan nilai noise yang dihasilkan setiap objek dengan latar belakang yang dihasilkan melalui citra hasil threshold sebelumnya.

$$
\begin{aligned}
& \text { for }(x=0 ; I<8=i++) \\
& \text { for }(y=0 ; y<8=y++)
\end{aligned}
$$

\section{Proses Shift Vector}

Pada proses ini sistem melakukan proses untuk mencari persamaan nilai pixel tersebut dan menentukan nilai setiap baris dan kolom yang dihasilkan pixel dengan jumlah nilai yang dihasikan sehingga, nilai pixel tersebut menjadi lebih jelas dimana wilayah setiap baris dan kolom yang menggunakan citra copymove dan membantu kerja sistem dalam menentukan jumalah bloking yang dihasilkan oleh citra tersebut

\section{Hasil Blok Citra}

Pada proses ini merupakan hasil yang diterima oleh proses sebelumnya yaitu nilai pixel yang sudah terindikasi merupakan citra copymove sehingga dapat mempermudah sistem dalam menentukan jumlah bloking yang akan digunakan untuk setiap wilayah citra tersebut.

\section{HASIL DAN PEMBAHASAN}

Implementasi perangkat lunak merupakan proses untuk penerapan perangkat lunak yang baru. Perangkat lunak baru ini akan dioperasikan secara menyeluruh, sesuai dengan Analisa dan perancangan yang dilakukan di bab sebelumnya. Berikut merupakan tampilan dari implementasi aplikasi Discrite Wavelet Transform (DWT) dalam melakukan proses mendeteksi citra yang menggunakan Teknik copymove.

\section{Tampilan Form Aplikasi Discrete Wavelet Transform (Dwt)}

Gambar 3. dibawah merupakan tampilan dari form Discrete Wavelet Transform (DWT). Pada form tersebut citra Copymove diinputkan kedalam sistem dengan memilih citra di PC. Citra copymove yang di inputkan, sesuai dengan ketentuan yang ada dalam sistem yaitu JPG, PNG dan BMP. Apabila citra yang diinputkan tidak sesuai dengan ketentuan yang ada pada sistem, maka akan muncul pesan pemberitahuan mengenai citra tersebut di Priview seperti gambar 4 dan gambar 5

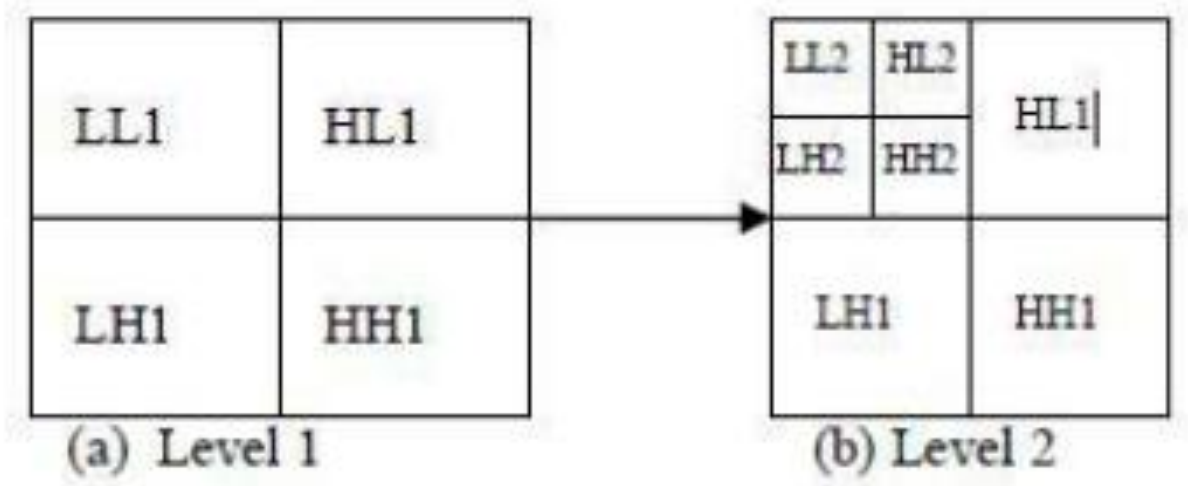

Gambar 2. Dekomposisi wavelet 

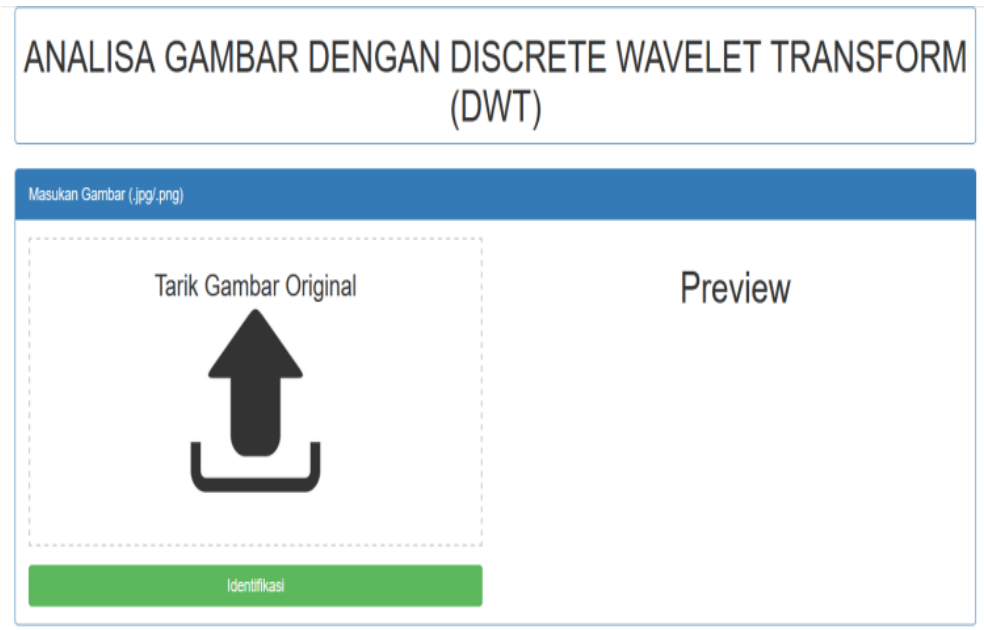

Gambar 3. Halaman form aplikasi Discrete Wavelet Transform (DWT)

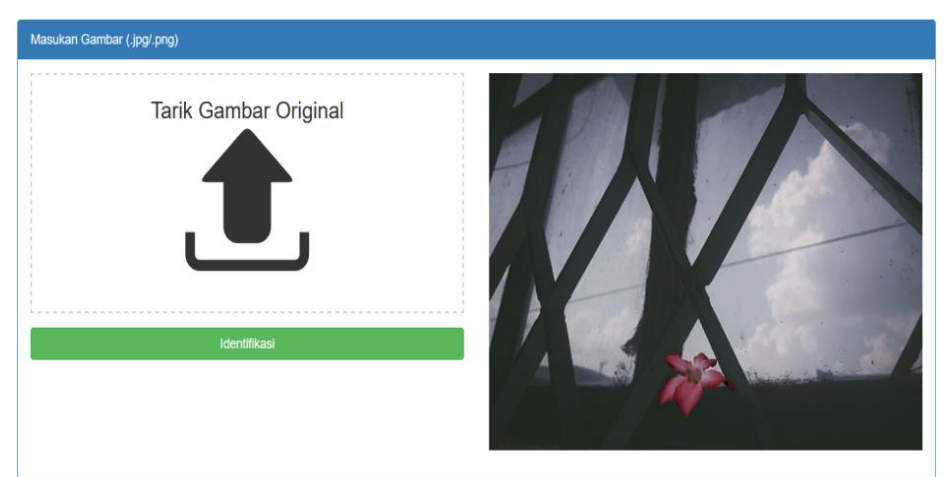

Gambar 4. Proses input gambar

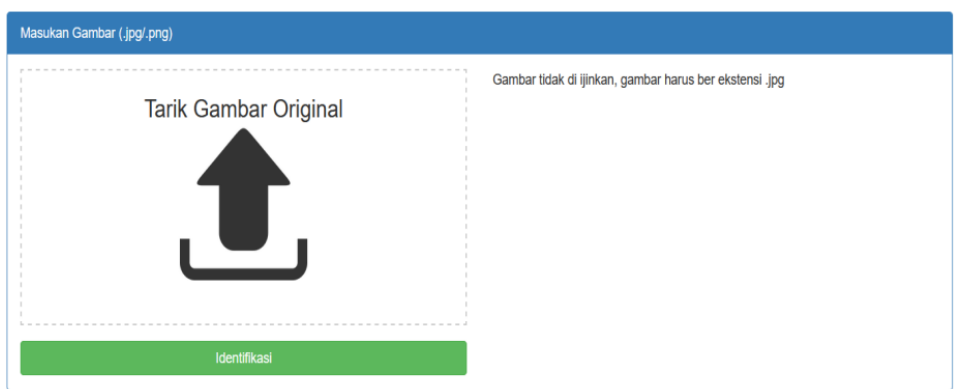

Gambar 5.. Proses citra yang tidak sesuai ketentuan di sistem

\section{Implementasi dalam Mendeteksi Citra} Copymove

1. Menginput Citra

2. Proses dalam menginput citra dibutuhkan sebuah data berupa citra asli dan citra palsu yang memiiki format yang diminta oleh sistem yaitu JPG, PNG dan BMP. Citra tersebut akan digunakan sebagai sampel dalam menjalankan sistem untuk mendeteksi citra copymove. Berikut data sampel untuk mendeteksi citra copymove yang dapat dilihat pada table 1,Tabel di dibawah merupakan bentuk objek penelitian yang akan digunakan untuk melakukan proses identifikasi citra yang terdapat Teknik copymove 
di daerah citra tersebut. Pada citra tersebut merupakan citra yang didapat dari hasil dari citra continue yang menggunakan kamera digital dalam mengambil citra dan citra palsu. Keduanya digunakan sebagai sampel dalam melakukan proses identifikasi hasil dari image forgery dengan menggunakan Teknik copymove pada citra 2D. Citra tidak sesuai format

Pada tahapan ini, objek penelitian yang di proses harus memenuhi kriteria yang di tentukan dalam sistem, dalam hal ini sistem menentukan tiga format yaitu format JPG, PNG dan BMP untuk mendeteksi citra RGB, apabila terjadi kesalahan, maka sistem akan langsung menolak dengan memberikan pesan bahwa citra dengan format tersebut tidak sesuai dengan yang dibutuhkkan sistem. Berikut merupakan hasil dari proses sistem yang tidak menerima format lain selain dari yang ditentukan yang dapat dilihat pada gambar 5. di atas.

\section{Konversi Citra RGB ke Grayscale}

Pada tahapan ini, data sampel berupa citra RGB akan mengalami proses awal dari sistem dengan mengkonversi citra asli dan citra palsu menjadi citra yang memiliki warna putih keabuan (grayscale) tetapi, sebelum citra menjadi putih keabuan. Citra tersebut akan terlebih dahulu dilakukan proses pengambilan RGB dari pixel setelah proses tersebut citra akan melakukan proses ekstrak RGB. Proses ini citra akan dihitung berapa nilai Red, Grean dan Blue yang dihasilkan oleh pixel setelah mendapat nilainya, citra akan dibagi 3 . Hasil dari bagi 3 tersebut merupakan nilai dari pixel yang dihasilkan untuk citra grayscale apabila citra memiliki resolusi 200x200, maka nilai dihasilkan oleh proses menghitung RGB dan dibagi 3 sebanyak 4000 pixel untuk nilai citra grayscale. Berikut hasil konversi Grayscale yang dapat dilihat pada tabel 2 di bawah.

\section{Proses Threshold}

Pada proses ini merupakan proses lanjutan dari grayscale sebelumnya, fungsi dari proses ini untuk mengkategorikan setiap nilai pixel dari citra grayscale yang di dapat sebelumnya. Nilai citra grayscale tersebut didapat dari perhitungan berapa nilai Red, nilai Grean dan nilai Blue dan nilai tersebut dibagi 3 dalam proses ini, nilai yang ditentukan untuk nilai Threshold tersebut adalah 90 apabila, hasil perhitungan untuk nilai pixel pada citra grayscale tersebut kurang dari nilai Threshold maka akan di ganti menjadi warna merah tetapi, apabila melewati nilai threshold maka akan diganti dengan warna putih. Berikut merupakan citra yang diganti berdasarkan nilai pixel dari citra grayscale sebelumnya yang dapat dilihat pada tabel 3.

Tabel 1. Citra Asli dan Citra Copymove

\begin{tabular}{|c|c|c|c|}
\hline Citra Asli & Citra Palsu & Ket. & Format \\
\hline & & Citra yang menampilkan daun di atas lantai & \\
\hline & & & JPG \\
\hline$=1$ & & $\begin{array}{l}\text { Citra yang menampilkan satu objek berupa } \\
\text { mainan mobil yang ada di lantai }\end{array}$ & PNG \\
\hline
\end{tabular}




Citra yang menampilkan sutu objek berupa toples
yang ada di atas lantai

Tabel 2. Konversi grayscale

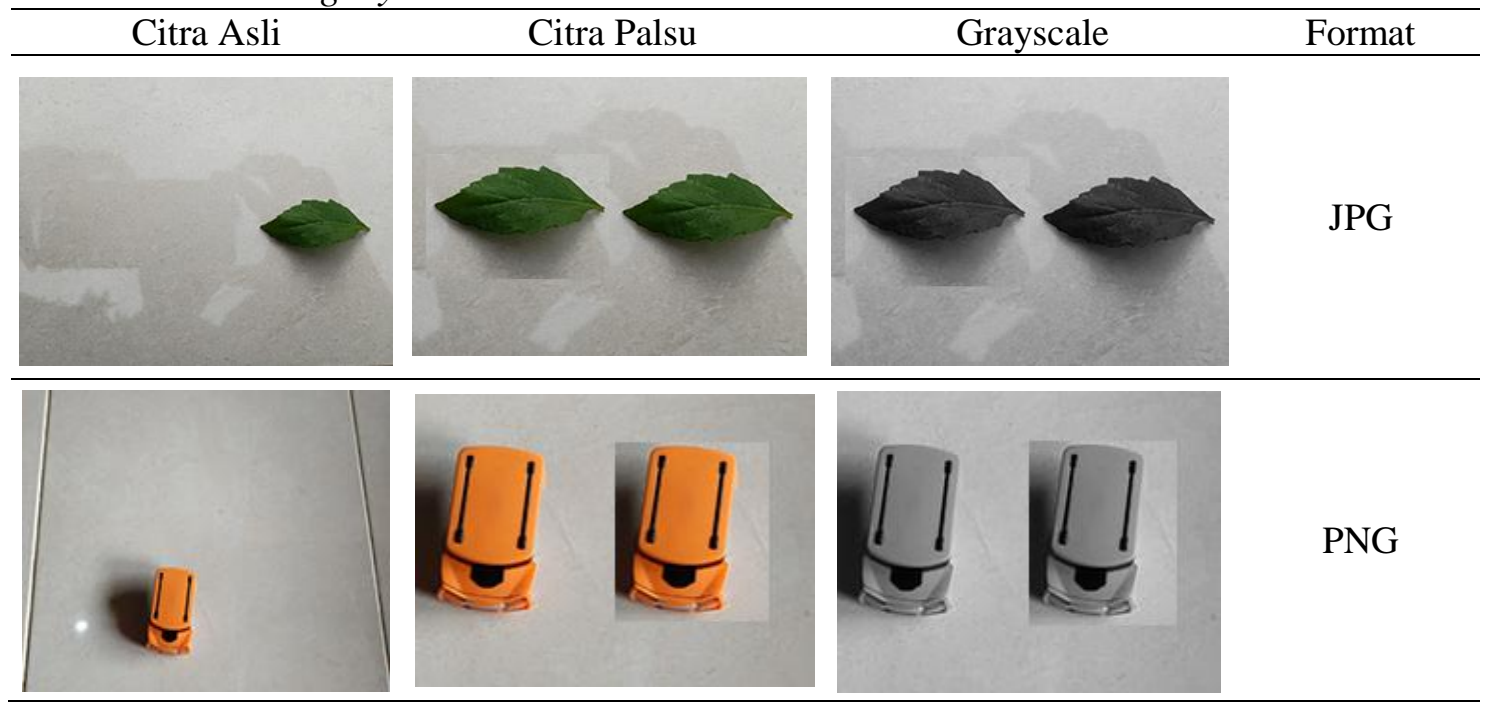

Tabel 3. Hasil Threshold

\begin{tabular}{rrrr}
\hline & Hasil Threshold & & Format Citra \\
\hline Citra Asli & Citra Palsu & JPG \\
\hline & & PNG & BMP \\
\hline
\end{tabular}

\section{Dekomposisi DWT}

Proses ini merupakan langkah untuk mulai membagi ukuran gambar dari setiap level dari dekomposisi DWT seperti gambar yang dihasilkan berukuran $2 \times 2$ pada level $\mathrm{L}$ akan mengalami pengurangan ukuran menjadi $2 i / 2 \times 2 i / 2$ pixel. Citra akan dibagi kedalam 4 subband dalam proses DWT ini menjadi label LL, LH, HL, dan HH. Berikut merupakan hasil dari proses sistem dalam membagi citra menjadi 4 sub setelah dibagi menjadi 4 subband dibagi lagi menjadi 4 subband sampai mendapat berapa nilai dari setiap subband tersebut. Fungsi dari dekomposisi ini adalah untuk menentukan berapa nilai yang dihasilkan dari setiap subband hasil dari proses dekomposisi DWT. Tabel di atas merupakan hasil dari proses algoritma dalam membagi citra menjadi 4 subband LL, LH, HL, dan HH untuk mendapatkan nilai noise yang dihasilkan oleh citra copymove tersebut. Setelah melakukan 
proses threshold citra tersebut, akan melakukan proses dekomposisi dengan lebih berfokus dengan mengolah objek yang dihasilkan citra dan mengutama nilai yang dihasilkan oleh objek. Dapat dilihat pada tabel 4

Tabel 4. Dekomposisi DWT

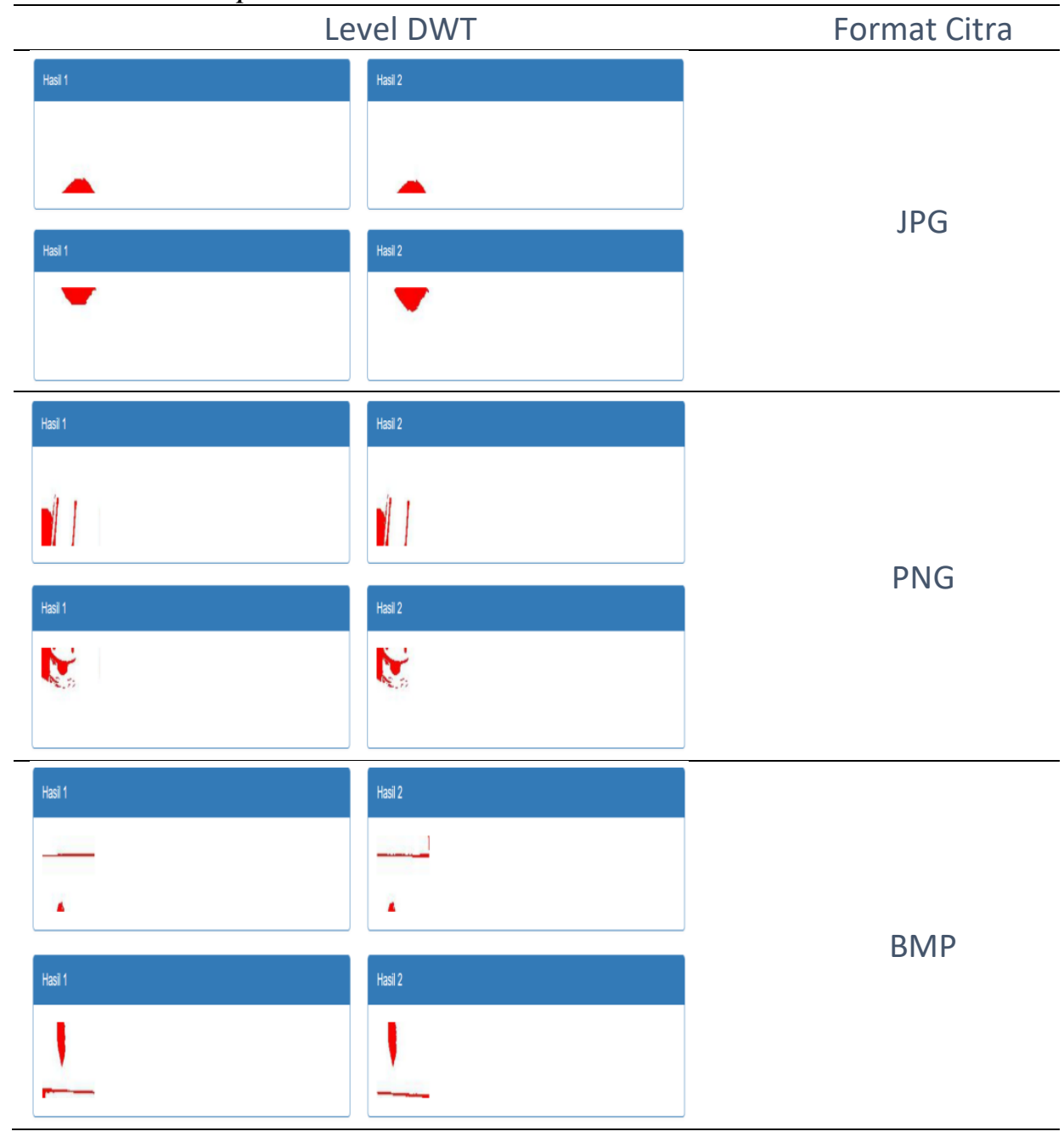

Tabel 5. Nilai Pixel Dekomposisi

\begin{tabular}{|c|c|c|c|c|}
\hline \multicolumn{4}{|c|}{ Nilai Pixel Dekomposisi } & \multirow{2}{*}{$\begin{array}{c}\text { Format } \\
\text { Citra }\end{array}$} \\
\hline \multicolumn{2}{|c|}{ Citra Asli } & \multicolumn{2}{|c|}{ Citra Palsu } & \\
\hline $\operatorname{man} x$ & $m \rightarrow$ & 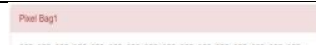 & Presen & \\
\hline 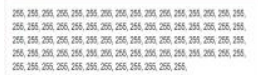 & 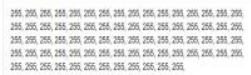 & 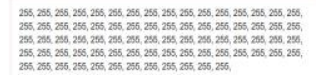 & 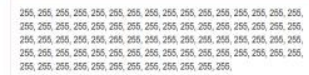 & \\
\hline$+\infty$ & $m$ & $m \rightarrow$ & $m \rightarrow \infty$ & JPG \\
\hline 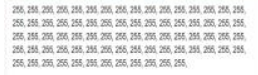 & 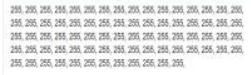 & 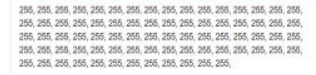 & 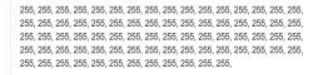 & \\
\hline
\end{tabular}




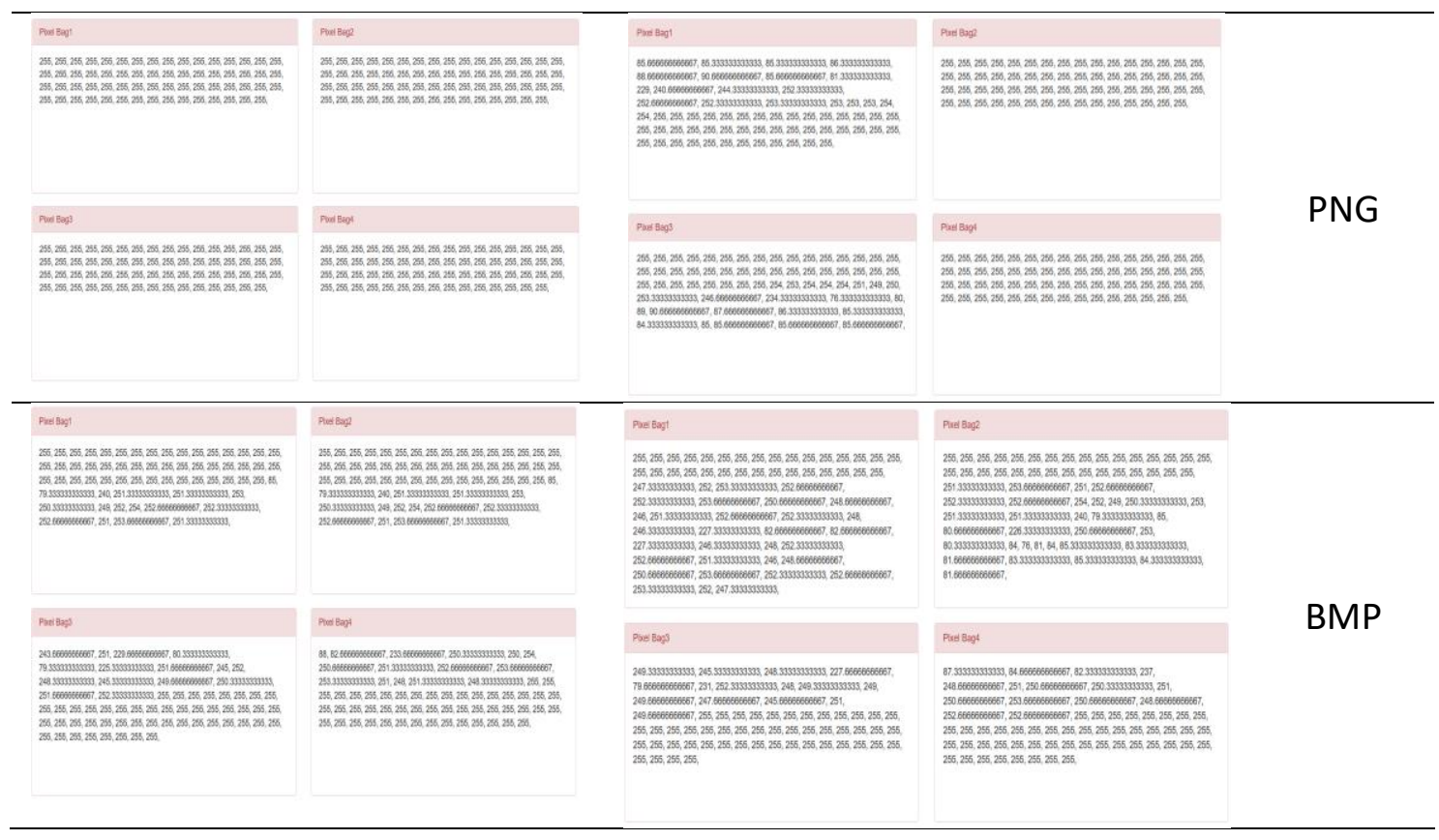

Tabel di atas merupakan hasil dari penghitungan dari algoritma DWT, fungsi dari langkah ini hampir sama dengan langkah sebelumnya. Langkah ini digunakan untuk menghitung setiap pixel yang dihasilkan oleh subband tersebut menggunakan matrik 8x8 sehingga, untuk menghitung pixel tersebut setiap satu matrik $8 \times 8$ itu merupakan kumpulan dari beberapa pixel maka dari keseluruhan pixel yang dihasilkan citra, terdapat beberapa matrik yang dihasilkan, sehingga dari matrik tersebut akan diperoleh berapa jumlah pixel yang mengenai objek dengan nilai yang dimiliki sama dengan nilai objek di daerah citra lain dan memiliki perbedaan nilai antara objek tersebut dengan nilai yang di sekitarnya.

\section{Proses Shift Vektor}

Pada proses ini, sistem akan menentukan nilai dari hasil proses perhitungan matrik $8 \times 8$ dengan menentukan persamaan dari nilai tersebut dan menentukan baris dan kolom untuk nilai yang di indikasi sebagai nilai dari proses copymove sehingga, mempermudah sistem dalam menentukan proses akhir dari algoritma ini yaitu melakukan blok terhadap wilayah citra copymove. Fungsi shift vector merupakan untuk menentukan baris dan kolom yang di indikasikan terdapat image forgery dengan menggunakan Teknik copymove dan mengelompokkan nilai pixel setiap baris sehingga, memudahkan sistem dalam menentukan bloking pada daerah citra dan shift vector berperan untuk menyimpan hasil dari nilai bloking tersebut ke dalam database. Berikut merupakan hasil nilai yang di indikasikan merupakan nilai hasil image forgery menggunakan Teknik copymove :

Hasil dari proses shift vector dalam menentukan persamaan nilai dan mencari baris dalam kolom setiap pixel yang diindikasi merupakan nilai hasil dari proses copymove pada citra sehingga, dapat mempermudah sistem dalam menentukan hasil akhir untuk citra copymove yaitu melakukan proses bloking. Proses ini berhasil dilakukan setelah menerima nilai yang dihasilkan oleh proses sistem sebelumnya dalam menentukan nilai pixel menggunakan matrik 8x8 untuk setiap nilai subband LL, LH, HL, HH yang dihasil oleh proses 
dekomposisi untuk citra dan proses ini membantu sistem dalam mencari perbedaan yang dihasilkan oleh copymove tersebut .

\section{Hasil bloking citra}

Proses ini merupakan tahap akhir dalam sistem untuk menemukan wilayah citra yang di terindikasi, melakukan proses image forgery dengan menggunakan salah satu Teknik yaitu citra copymove. pada proses ini sistem akan melakukan proses bloking terhadap citra dengan mengambil setiap pixel pada citra yang memiliki nilai yang berbeda di sekitar objek tetapi sama dengan objek yang berada di wilayah citra yang lain. Berikut merupakan hasil dari proses mendeteksi citra copymove dengan menguji setiap format yaitu JPG, PNG dan BMP, dengan masing-masing format memiliki 16 citra yang berbeda.
Tabel di atas merupakan tabel hasil dari proses sistem dalam mendeteksi copymove pada keseluruhan citra, dalam mendeteksi citra copymove. pada tabel tersebut terdapat beberapa citra yang di kategorikan merupakan citra yang memiliki daerah false match dengan citra yang tanpa memiliki daerah false match. False Match merupakan daerah-daerah yang dalam pengujian terdapat blok pada daerah citra, daerah citra tersebut sebenarnya bukan merupakan daerah copymove tetapi, memiliki blok yang bernilai sama.

Berikut adalah table 8 yang merupakan hasil dari proses sistem dalam menentukan perbedaan citra yang hasil dari proses copymove dengan citra asli dengan menentukan nilai setiap pixel pada citra sehingga, dapat melihat persamaan nilai dari daerah citra tersebut menggunakan algoritma DW.

Tabel 6. Hasil Pengujian menggunakan Blok 8x8 Citra

\section{BLOK 8 X 8}

\begin{tabular}{|c|c|c|c|c|}
\hline Format & Total Citra & Model Deteksi & & Akurasi \\
\hline \multirow{3}{*}{ JPG } & \multirow{3}{*}{16} & Terdeteksi sempurna daerah copymove & 7 & $43,75 \%$ \\
\hline & & Terdeteksi Sebagian daerah copymove & 8 & $50 \%$ \\
\hline & & $\begin{array}{l}\text { Tidak terdeteksi sama sekali daerah } \\
\text { copymove. }\end{array}$ & 1 & $6,25 \%$ \\
\hline \multirow{3}{*}{ PNG } & \multirow{3}{*}{16} & Terdeteksi sempurna daerah copymove & 6 & $37,5 \%$ \\
\hline & & Terdeteksi Sebagian daerah copymove & 10 & $62,5 \%$ \\
\hline & & $\begin{array}{l}\text { Tidak terdeteksi sama sekali daerah } \\
\text { copymove. }\end{array}$ & 0 & $0 \%$ \\
\hline \multirow{3}{*}{ BMP } & \multirow{3}{*}{16} & Terdeteksi sempurna daerah copymove & 5 & $31,25 \%$ \\
\hline & & Terdeteksi Sebagian daerah copymove & 10 & $62,5 \%$ \\
\hline & & $\begin{array}{l}\text { Tidak terdeteksi sama sekali daerah } \\
\text { copymove. }\end{array}$ & 1 & $6,25 \%$ \\
\hline
\end{tabular}


Tabel 7. Hasil Pengujian Citra

\begin{tabular}{cclll}
\hline \multicolumn{5}{c}{ BLOK 8 X 8 } \\
\hline Format & $\begin{array}{c}\text { Format } \\
\text { Citra }\end{array}$ & \multicolumn{1}{c}{ Daerah False Match } & \multirow{2}{*}{ False Match } \\
\hline \multirow{2}{*}{ JPG } & \multirow{2}{*}{16} & Citra dengan daerah false match & 9 & $56,25 \%$ \\
\cline { 3 - 5 } & \multirow{2}{*}{ PNG } & \multirow{2}{*}{ Citra tanpa daerah false match } & 7 & $43,75 \%$ \\
\cline { 3 - 5 } & \multirow{2}{*}{ BMP } & Citra dengan daerah false match & 7 & $43,75 \%$ \\
\cline { 3 - 5 } & & Citra tanpa daerah false match & 9 & $56,25 \%$ \\
\cline { 3 - 5 } & & Citra dengan daerah false match & 5 & $31,25 \%$ \\
\hline
\end{tabular}

Tabel 8. Perbedaan citra asli dan citra palsu

\begin{tabular}{|l|l|l|}
\hline Citra Asli & Citra Palsu & Format Citra \\
\hline & & JPG \\
\hline & & \\
\hline & & \\
\hline
\end{tabular}

\section{KESIMPULAN DAN SARAN}

Berdasarkan hasil penelitian ini maka dapat disimpulkan bahwa, aplikasi dapat mendeteksi noise ada citra copymove, dengan identifikasi nilai noise yang dihasilkan setiap pixel pada citra. Citra yang berhasil di identifikasi akan menghasil citra yang memiliki bloking pada daerah citra untuk menandakan bahwa citra tersebut melakukan proses image forgery dengan Teknik copymove dengan, memiliki nilai yang sama dengan objek/daerah citra yang lain.

\section{DAFTAR PUSTAKA}

Al-gaufiqy, M., Rasmana, S., \& Puspasari, ira. (2017). Journal of
Control and Network Systems. Journal of Control and Network Systems, 6(1), 73-86.

Amin, M., Fitri, S., Zi, W., Demon, H., Citra, L., Rekonstruksi, H., \& Perancangan, D. (2015). Perancangan Perangkat Lunak Rekonstruksi Citra 3 Dimensi Dari Lembaran Citra Hasil Rekonstruksi 2 Dimensi. PRIMA, 12(November). Aminudin, M. (2018). kasus dosen brawijaya. Detik News. Retrieved from https://news.detik.com/beritajawa-timur/d-4136258/polisipelajari-kasus-dosen-brawijayakorban-edit-foto-netizen

Derwin Rony Sina, A. harjoko. (2016). 
Deteksi Copy Move Forgery Pada Citra Menggunakan Exact Match, DWT Haar dan Daubechies. IJEIS, 6(1).

Lesmana, agung sandi. (2019). Berstatus tersangka. Suarajatim.Id.

Lizarti, N., Sugiantoro, B., \& Prayudi, Y. (2017). Penerapan Composite Logic Dalam Mengkolaborasikan. JISKa, 2(1), 26-33.

Purwandari, E. P., Vatresia, A., \& Siburian, S. (2019). DETEKSI IMAGE SPLICING PADA CITRA DENGAN METODE DISCRETE COSINE TRANSFORM ( DCT ) DAN SCALE INVARIANT FEATURE TRANSFORM ( SIFT ). Jurnal Pseudocode,
VI(September), 138-148.

Vega, E. A. A., Orozco, A. L. S., Villalba, L. J. G., \& Hernandez-Castro, J. (2018). Digital images authentication technique based on DWT, DCT and local binary patterns. Sensors (Switzerland), 18(10), 1-18. https://doi.org/10.3390/s18103372

Yan Mitha Djaksana, A. K. R. (2018). ANALISIS MANIPULASI CITRA ( IMAGE FORGERY ) MENGGUNAKAN INTEGRASI METODE ERROR LEVEL ANALYSIS DAN BLOCK MATCHING. XII(01), 83-89. 